\title{
Aprepitant in combination with palonosetron for the prevention of postoperative nausea and vomiting in female patients using intravenous patient-controlled analgesia
}

\author{
Jae Hwa Yoo, Soon Im Kim, Ji Won Chung, Mi Roung Jun, Yoo Mi Han, and \\ Yong Jik Kim \\ Department of Anesthesiology and Pain Medicine, Soonchunhyang University Seoul Hospital, Seoul, Korea
}

\begin{abstract}
Background: The aim of this study was to evaluate aprepitant in combination with palonosetron as compared to palonosetron alone for the prevention of postoperative nausea and vomiting (PONV) in female patients receiving fentanyl-based intravenous patient-controlled analgesia (IV-PCA).

Methods: In this randomized single-blinded study, 100 female patients scheduled for elective surgery under general anesthesia were randomized to two groups: Group AP $(80 \mathrm{mg}$ aprepitant plus $0.075 \mathrm{mg}$ palonosetron, $\mathrm{n}=50)$ and Group $\mathrm{P}$ $(0.075 \mathrm{mg}$ palonosetron, $\mathrm{n}=50)$. The patients in group AP received $80 \mathrm{mg}$ aprepitant per oral $1-3 \mathrm{~h}$ before surgery, while all patients received $0.075 \mathrm{mg}$ palonosetron after induction of standardized anesthesia. All patients had postoperative access to fentanyl-based IV-PCA. The incidence of nausea and vomiting, use of rescue medication, and severity of nausea were evaluated at 6 and $24 \mathrm{~h}$ after surgery.

Results: The incidence of nausea (54\%) and vomiting (2\%) in group AP did not differ significantly from that in group P (48\% and $14 \%$, respectively) during the first $24 \mathrm{~h}$ after surgery $(\mathrm{P}>0.05)$. Patient requirements for rescue medication in group AP (29\%) were similar to those in group P (32\%) at $24 \mathrm{~h}$ after surgery $(\mathrm{P}>0.05)$. There was no difference between the groups in severity of nausea during the first $24 \mathrm{~h}$ after surgery $(\mathrm{P}>0.05)$.

Conclusions: Aprepitant combined with palonosetron did not reduce the incidence of PONV as compared to palonosetron alone within $24 \mathrm{~h}$ of surgery in women receiving fentanyl-based IV-PCA.
\end{abstract}

Keywords: Aprepitant; Palonosetron; Postoperative nausea and vomiting.

Corresponding author: Soon Im Kim, M.D., Ph.D.

Department of Anesthesiology and Pain Medicine, Soonchunhyang University Seoul Hospital, 59 Daesagwan-gil, Yongsan-gu, Seoul 04401, Korea Tel: 82-2-709-9302, Fax: 82-2-790-0394

Email: soonnim@schmc.ac.kr

ORCID: https://orcid.org/0000-0001-8884-4096

It was presented at Euroanaesthesia 2017 of The European Anaesthesiology Congress, May 2017, Geneva Business Center, Geneva, Switzerland.

Received: January 12, 2018. Revised: February 20, 2018 (1st); April 27, 2018 (2nd) Accepted: April 28, 2018.

Korean J Anesthesiol 2018 December 71(6): 440-446

https://doi.org/10.4097/kja.d.18.00011

(c) This is an open-access article distributed under the terms of the Creative Commons Attribution Non-Commercial License (http://creativecommons.org/ licenses/by-nc/4.0/), which permits unrestricted non-commercial use, distribution, and reproduction in any medium, provided the original work is properly cited. 


\section{Introduction}

Despite advances in anesthesia and the widespread use of antiemetics, postoperative nausea and vomiting (PONV) are still a common and concerning problem that results in decreased patient satisfaction, delayed recovery, and increased hospital costs. The incidence of PONV has been reported to be $20 \%-50 \%$ and can be as high as $80 \%$ in patients at high-risk of PONV $[1,2]$.

The pathophysiology of PONV is still unclear. PONV has a multifactorial origin and is thought to occur through a variety of receptors including dopamine, serotonin, histamine, acetylcholine, and neurokinin-1 (NK1) receptors. To prevent PONV, various medications that target one of these receptors are used, including dopamine receptor antagonists, serotonin 5-hydroxytryptamine type $3\left(5-\mathrm{HT}_{3}\right)$ receptor antagonists, histamine receptor antagonists, anticholinergics, corticosteroids, and NK1 receptor antagonists [1,3].

Among these antiemetics, $5-\mathrm{HT}_{3}$ receptor antagonists are the most commonly used for the prevention of PONV because of their efficacy and low side-effect profile. $5-\mathrm{HT}_{3}$ receptor antagonists, such as ondansetron, dolasetron, tropisetron, and ramosetron, act on the $5-\mathrm{HT}_{3}$ receptor by competing with central and peripheral serotonin binding [4].

Palonosetron is a second-generation $5-\mathrm{HT}_{3}$ antagonist that has a longer half-life $\left(>40 \mathrm{~h}\right.$ ) and greater affinity to the $5-\mathrm{HT}_{3}$ receptor than older $5-\mathrm{HT}_{3}$ antagonists such as ondansetron, granisetron, and ramosetron. Palonosetron has a distinct chemical structure, mechanism of action, and pharmacodynamic profile compared to older $5-\mathrm{HT}_{3}$ antagonists. It exhibits allosteric binding and positive cooperativity with the $5-\mathrm{HT}_{3}$ receptor and triggers $5-\mathrm{HT}_{3}$ receptor internalization leading to its long duration of action [5]. Palonosetron is effective in preventing chemotherapy-induced nausea and vomiting (CINV) in both acute $(0-24 \mathrm{~h})$ and delayed settings $(24-120 \mathrm{~h})$. It is the only $5-\mathrm{HT}_{3}$ receptor antagonist approved for both acute and delayed CINV [6-8]. Palonosetron is effective for the prevention of PONV and was approved in 2008, at a dose of $0.075 \mathrm{mg}$ intravenously, by the US Food and Drug Administration (FDA) for the prevention of PONV for up to $24 \mathrm{~h}$ post-surgery [9-11].

Aprepitant is a highly selective antagonist at the NK1 receptor with a half-life of $40 \mathrm{~h}$. Substance $\mathrm{P}$ is an endogenous ligand for the NK1 receptor and is a potent inducer of emesis. NK1 receptors are located in the gut, in the area postrema and the nucleus tractus solitarius; these areas are involved in the emesis reflex. Like serotonin, substance $\mathrm{P}$ is released by emetogenic chemotherapies and appears to act on receptors that are both peripherally and centrally located. Aprepitant crosses the blood-brain barrier and can act on both central and peripherally located NK1 receptors. An advantage of aprepitant is its strong anti-emetic effect in both the acute and delayed periods.
Aprepitant is effective for the prevention of acute CINV, but most importantly is effective in delaying CINV when combined with $5-\mathrm{HT}_{3}$ antagonists or dexamethasone [12,13]. Therefore, it has been endorsed as part of a three-drug combination (an NK1 receptor antagonist, a 5- $\mathrm{HT}_{3}$ receptor antagonist, and dexamethasone) for the prevention of CINV [14]. For the prevention of PONV, aprepitant is effective for up to $24 \mathrm{~h}$ post-surgery and has been demonstrated to be more effective than ondansetron for preventing vomiting at 24 and $48 \mathrm{~h}$ post-surgery [15-17]. Aprepitant was the first NK1 receptor antagonist for PONV approved by the US FDA [3].

To date, no single antiemetic agent has shown the ability to eliminate PONV; therefore, combination antiemetic therapy with two or more classes of agents is recommended rather than monotherapy to prevent PONV in high-risk patients [1].

Recently, it was reported that a combination of aprepitant with ramosetron was more effective than ramosetron alone for the prevention of PONV in high-risk patients [18]. However, there are no reports about combination therapy using aprepitant and palonosetron to prevent PONV, although combination therapy using aprepitant, palonosetron, and dexamethasone has been used for the prevention of CINV [14].

We hypothesized that the combination of aprepitant and palonosetron might be superior to palonosetron alone for the prevention of PONV in high-risk patients. We compared the effect of aprepitant in combination with palonosetron to that of palonosetron alone in women at high risk for PONV, who received opioid-based intravenous patient-controlled analgesia (IV-PCA).

\section{Materials and Methods}

This prospective, single-blinded randomized controlled trial was approved by our hospital's Institutional Review Board (No. 2012-159) and was registered in the clinical trials registry (KCT0002433).

The trial included 100 female patients aged 20-70 years with an American Society of Anesthesiologists physical status rating of I-II, who used IV-PCA for postoperative pain control after elective surgery under general anesthesia.

Exclusion criteria included the presence of allergies to palonosetron, aprepitant, nonsteroidal anti-inflammatory drugs or opioids, the use of antiemetic drugs, or steroid medication within $24 \mathrm{~h}$ of surgery, nausea or vomiting within $24 \mathrm{~h}$ of surgery, dementia or communication difficulties, a history of severe respiratory or cardiovascular disease, a history of gastrointestinal, neurologic, liver, or renal disease, pregnancy, and severe obesity.

All patients were given information about the trial and all provided written informed consent. Patients were divided randomly by a computer-generated number table into Group AP (80 
mg oral aprepitant [Emend ${ }^{\circledR}$, MSD Korea, Korea] plus $0.075 \mathrm{mg}$ intravenous palonosetron, $\mathrm{n}=50)$ or Group P (0.075 mg intravenous palonosetron, $\mathrm{n}=50$ ).

The patients allocated to group AP received $80 \mathrm{mg}$ aprepitant peroral with water $2-3 \mathrm{~h}$ prior to their surgery. All patients received $0.2 \mathrm{mg}$ glycopyrrolate intramuscularly on the ward 30 min before surgery. On arrival in the operating theatre, standard monitoring was performed, including non-invasive blood pressure, peripheral oxygen saturation, and electrocardiography.

General anesthesia was standardized for each patient. Anesthesia was induced using a bolus of $2 \mathrm{mg} / \mathrm{kg} 1 \%$ propofol and 40 mg $2 \%$ lidocaine followed by continuous infusion of remifentanil $(0.05-0.5 \mu \mathrm{g} / \mathrm{kg} / \mathrm{min})$. After the loss of consciousness, 0.6 $\mathrm{mg} / \mathrm{kg}$ rocuronium was administered for muscle relaxation and endotracheal intubation was performed. Anesthesia was maintained with inhaled anesthetics (desflurane or sevoflurane) in $50 \%$ oxygen with continuous infusion of remifentanil. After induction of anesthesia, $0.075 \mathrm{mg}$ of palonosetron was administered intravenously to all patients. At the end of the surgical procedure, neuromuscular relaxation was reversed with pyridostigmine and glycopyrrolate, and patients were extubated. All patients received fentanyl-based IV-PCA postoperatively.

When a patient complained of moderate to severe nausea or vomiting, intravenous metoclopramide $(10 \mathrm{mg}$ ) was administered. If this did not improve their condition, $4 \mathrm{mg}$ intravenous ondansetron was injected as a supplementary treatment.

Our primary end-point was the incidence of PONV during the $24 \mathrm{~h}$ postoperative period, with secondary end-points of nausea severity, use of rescue medication, patient satisfaction, and adverse events.
All patients were interviewed regarding the occurrence of nausea and vomiting and were asked to rank their nausea using a four-point verbal rating scale $(0=$ none, $1=$ mild, $2=$ moderate, 3 = severe). The use of rescue medication and other adverse effects of IV-PCA or antiemetics were also noted at 1, 6, and 24 $\mathrm{h}$ postoperatively. Patient satisfaction at $24 \mathrm{~h}$ post-surgery was quantified using a three-point scale $(0=$ dissatisfied, $1=$ neither satisfied nor dissatisfied, 2 = satisfied).

Candiotti et al. [10] reported a PONV incidence of 57\% when using $0.075 \mathrm{mg}$ palonosetron, whereas Lee et al. [18] reported an absolute rate of reduction of $30 \%$ when using aprepitant combined with ramosetron. Based on these two reports, 42 patients were required per group for a one-sided $\alpha=0.05$ at a power of $90 \%$; assuming a drop-out rate of $20 \%$, in total, 50 patients were required for the study. Statistical analyses were performed using SPSS Statistics for Windows, ver. 14.0 (SPSS Inc., USA). The categorical data were analyzed using a chi-squared or Fisher's exact test and presented as frequencies with percentages. The continuous data were analyzed using Student's $t$-test and presented as mean \pm SD. A P value of $<0.05$ was considered statistically significant.

\section{Results}

In total, 115 patients were screened, among whom 100 were enrolled in the study and divided randomly into two groups. Of the study patients, nine in group AP and five in group $\mathrm{P}$ were excluded from the study due to protocol violations, while one patient in group $\mathrm{P}$ withdrew as the surgery was canceled. Data obtained from the remaining 85 patients were analyzed, with 41

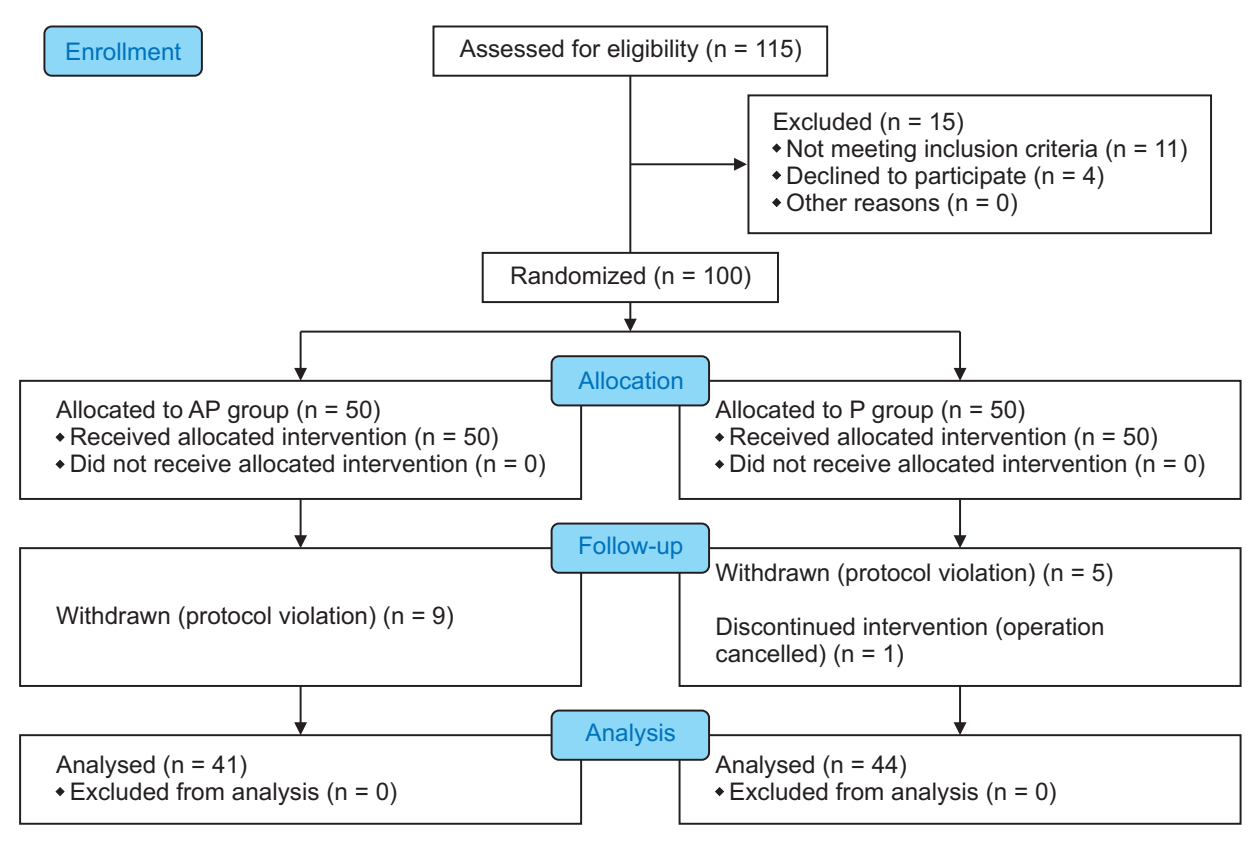

Fig. 1. CONSORT diagram. AP group: $80 \mathrm{mg}$ aprepitant per oral plus $0.075 \mathrm{mg}$ palonosetron intravenously, $\mathrm{P}$ group: $0.075 \mathrm{mg}$ palonosetron alone. 
Table 1. Baseline Characteristics

\begin{tabular}{lccc}
\hline & $\begin{array}{c}\text { AP group } \\
(\mathrm{n}=41)\end{array}$ & $\begin{array}{c}\text { P group } \\
(\mathrm{n}=44)\end{array}$ & P value \\
\hline Age (yr) & $52 \pm 12$ & $52 \pm 12$ & 0.887 \\
Weight $(\mathrm{kg})$ & $60 \pm 9$ & $62 \pm 9$ & 0.337 \\
History of PONV & $5(12 \%)$ & $4(9 \%)$ & 0.733 \\
History of motion sickness & $17(41 \%)$ & $13(30 \%)$ & 0.251 \\
Smoker & $2(5 \%)$ & $6(14 \%)$ & 0.268 \\
Type of surgery & & & 0.780 \\
$\quad$ Major orthopedic operation & $35(85 \%)$ & $35(80 \%)$ & \\
Thyroidectomy & $2(5 \%)$ & $2(5 \%)$ & \\
$\quad$ Laparoscopic hysterectomy & $1(2 \%)$ & $3(7 \%)$ & \\
$\quad$ Laparoscopic cholecystectomy & $3(7 \%)$ & $4(9 \%)$ & \\
Duration of surgery (min) & $86 \pm 56$ & $89 \pm 60$ & 0.755 \\
Duration of anesthesia (min) & $129 \pm 56$ & $132 \pm 66$ & 0.831 \\
\hline
\end{tabular}

Values are expressed as mean \pm SD or number of patients $(\%)$. AP group: $80 \mathrm{mg}$ aprepitant per oral plus $0.075 \mathrm{mg}$ intravenous palonosetron, $\mathrm{P}$ group: $0.075 \mathrm{mg}$ intravenous palonosetron alone. PONV: postoperative nausea and vomiting.

Table 2. Incidence of Nausea and Vomiting, and Use of Rescue Antiemetic Medication during the First 24 Hours after Surgery

\begin{tabular}{lccc}
\hline & $\begin{array}{c}\text { AP group } \\
(\mathrm{n}=41)\end{array}$ & $\begin{array}{c}\text { P group } \\
(\mathrm{n}=44)\end{array}$ & P value \\
\hline 0-6 h & & & \\
$\quad$ Nausea & $20(49 \%)$ & $20(45 \%)$ & 0.829 \\
$\quad$ Vomiting & $1(2 \%)$ & $3(7 \%)$ & 0.617 \\
PONV & $20(49 \%)$ & $20(45 \%)$ & 0.829 \\
Rescue antiemetics & $11(27 \%)$ & $11(25 \%)$ & 1.000 \\
6-24 h & & & \\
Nausea & $7(17 \%)$ & $12(27 \%)$ & 0.305 \\
Vomiting & $0(0 \%)$ & $3(7 \%)$ & 0.242 \\
PONV & $7(17 \%)$ & $14(32 \%)$ & 0.137 \\
$\quad$ Rescue antiemetics & $2(5 \%)$ & $5(11 \%)$ & 0.435 \\
0-24h & & & \\
$\quad$ Nausea & $22(54 \%)$ & $21(48 \%)$ & 0.666 \\
$\quad$ Vomiting & $1(2 \%)$ & $6(14 \%)$ & 0.111 \\
PONV & $22(54 \%)$ & $23(52 \%)$ & 1.000 \\
$\quad$ Rescue antiemetics & $12(29 \%)$ & $14(32 \%)$ & 0.818 \\
\hline
\end{tabular}

Values are expressed as number of patients (\%). AP group: $80 \mathrm{mg}$ aprepitant per oral plus $0.075 \mathrm{mg}$ intravenous palonosetron, $\mathrm{P}$ group: $0.075 \mathrm{mg}$ intravenous palonosetron alone. PONV: postoperative nausea and vomiting.

patients in group AP and 44 patients in group $\mathrm{P}$ (Fig. 1).

The baseline characteristics of the patients, and their previous operation history, PONV history, motion-sickness history, smoking status, surgery type, duration of surgery, and duration of anesthesia were all similar between the groups $(\mathrm{P}>0.05$, Table 1).

The incidence of nausea (54\%) and vomiting (2\%) in group AP did not differ significantly from that in group $\mathrm{P}$ (48\% and $14 \%$, respectively) during the first $24 \mathrm{~h}$ after surgery $(\mathrm{P}>0.05$,

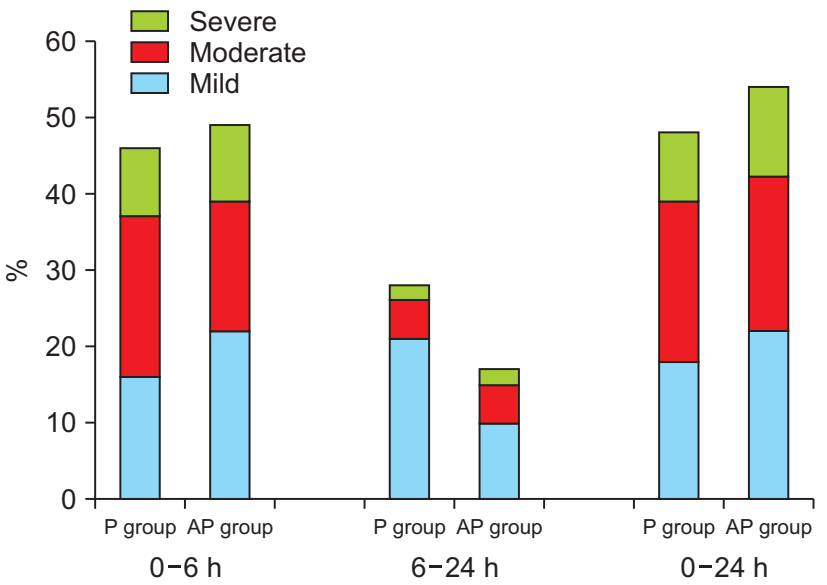

Fig. 2. Severity of nausea during the first $24 \mathrm{~h}$ after surgery. There was no significant difference in the severity of nausea between the groups during the first $24 \mathrm{~h}$ after surgery $(\mathrm{P}>0.05)$. AP group: $80 \mathrm{mg}$ aprepitant per oral plus $0.075 \mathrm{mg}$ intravenous palonosetron, $\mathrm{P}$ group: $0.075 \mathrm{mg}$ intravenous palonosetron alone.

Table 3. Incidence of Adverse Events and Patient Satisfaction during the First 24 Hours after Surgery

\begin{tabular}{cccc}
\hline & $\begin{array}{c}\text { AP group } \\
(\mathrm{n}=41)\end{array}$ & $\begin{array}{c}\text { P group } \\
(\mathrm{n}=44)\end{array}$ & P value \\
\hline Adverse effect & & & \\
Dizziness & $11(27 \%)$ & $12(27 \%)$ & 1.000 \\
Headache & $3(7 \%)$ & $4(9 \%)$ & 1.000 \\
Satisfaction & & & 0.127 \\
Satisfied & $36(88 \%)$ & $33(75 \%)$ & \\
Neutral & $3(7 \%)$ & $10(23 \%)$ & \\
Dissatisfied & $2(5 \%)$ & $1(2 \%)$ & \\
\hline
\end{tabular}

Values are expressed as number of patients (\%). AP group: $80 \mathrm{mg}$ aprepitant per oral plus $0.075 \mathrm{mg}$ intravenous palonosetron, $\mathrm{P}$ group: $0.075 \mathrm{mg}$ intravenous palonosetron alone.

Table 2). In group AP, $29 \%$ of patients required rescue medication within 24 h of surgery ( $\mathrm{P}>0.05$ ) compared to $32 \%$ of those in group $\mathrm{P}$ (Table 2). The severity of nausea during the first $24 \mathrm{~h}$ after surgery was similar in the two groups ( $P>0.05$, Fig. 2$)$ and there was no difference in satisfaction scores between the groups $(\mathrm{P}>0.05$, Table 3$)$. There was no significant difference in the rate of adverse effects between the groups $(P>0.05$, Table 3$)$.

\section{Discussion}

This study demonstrated that aprepitant combined with palonosetron did not reduce the incidence of PONV to a greater extent than palonosetron alone in the first $24 \mathrm{~h}$ after surgery in female patients receiving fentanyl IV-PCA for postoperative pain control.

Although the precise etiology of PONV is unknown, many risk factors are recognized, such as female sex, non-smoking 
status, history of PONV and/or motion sickness, use of volatile agents or nitrous oxide for anesthesia, use of postoperative opioids, and the duration and type of surgery [1]. Apfel et al. [19] reported four important independent risk factors: female sex, use of postoperative opioids, a history of PONV or motion sickness, and non-smoker status. Based on these four factors, a simplified risk score for predicting PONV was developed [19]. They suggested that the incidence of PONV increases to $10 \%$, $20 \%, 40 \%, 60 \%$, and $80 \%$ as the number of risk factors increases from 0 to $1,2,3$, and 4, respectively. In this study, the risk factors were equivalent between the groups, with most patients having an Apfel's risk score of 3 or 4 , which is considered a high risk for PONV.

In patients at high risk for PONV, it is recommended that antiemetic therapy combining two or more distinct classes of agents should be used to target the various receptors responsible for PONV [1]. While all antiemetic interventions act via independent mechanisms, their combined action is additive [20]. The most widely used combinations for the prevention of PONV are $5-\mathrm{HT}_{3}$ receptor antagonists combined with either dexamethasone, droperidol, or another antiemetic, and it has been shown that combination therapy is more effective than monotherapy $[1,21]$.

Recently, combination therapies using aprepitant and 5- $\mathrm{HT}_{3}$ receptor antagonists for PONV prevention have been reported. Vallejo et al. [22] reported that aprepitant combined with ondansetron significantly decreased postoperative vomiting (from $29.7 \%$ to $9.3 \%$ ) and nausea severity compared to ondansetron alone for up to $48 \mathrm{~h}$ postoperatively, even though the incidence of nausea was not significantly different. Trimas and Trimas [23] also reported improved immediate PONV when using $40 \mathrm{mg}$ aprepitant with ondansetron compared to ondansetron alone (from $15.5 \%$ to $1.8 \%$ ). Lee et al. [18] reported that compared to $0.3 \mathrm{mg}$ ramosetron alone and combination therapy using 80 mg aprepitant plus $0.3 \mathrm{mg}$ ramosetron significantly reduced the incidence of nausea and vomiting during the first $24 \mathrm{~h}$ postoperatively from $80.9 \%$ to $50 \%$ and $42.8 \%$ to $4.7 \%$, respectively, in gynecological patients using fentanyl IV-PCA. This represented relative risk reductions of $38 \%$ for nausea and $89 \%$ for vomiting. Thus, the anti-vomiting effect of this combination was more robust than the anti-nausea effect.

It has been reported that palonosetron inhibits signaling cross-talk between the $5-\mathrm{HT}_{3}$ and $\mathrm{NK} 1$ receptors: $5-\mathrm{HT}_{3}$ receptor internalization by palonosetron alters signaling cross-talk between $5-\mathrm{HT}_{3}$ and $\mathrm{NK} 1$ receptors, resulting in NK1 receptor internalization and NK1 receptor inhibition without direct binding to the NK1 receptor. In mechanistic studies using rodent-derived NG 108-15 cells, palonosetron and NK1 antagonists exerted an additive/synergic effect on substance-P-mediated inhibition. The authors suggested that the preventive effects of palonosetron and NK1 receptor antagonism on delayed emesis could be additive. However, these in vitro studies using rodent-derived cell models did not take into account species-specific differences in receptor locations and mechanisms of action. It is still unclear whether palonosetron's preventive effect against substance P on NK1 receptors is enhanced or negated in humans [13,24,25].

In contrast, studies of CINV have reported greater NK1 receptor antagonism when using netupitant combined with palonosetron and dexamethasone [26,27]. Therefore, we postulated that the combination of aprepitant and palonosetron would offer superior protection against PONV as compared to palonosetron alone, similar to the results observed for aprepitant and ondansetron or ramosetron combinations. However, our results reveal that when combined with palonosetron, aprepitant unexpectedly did not reduce the incidence of PONV as compared to palonosetron alone.

We offer possible explanations for our unexpected results cautiously. First, the results may be related to our evaluation period. In the CINV study, acute emesis was largely associated with activation of $5-\mathrm{HT}_{3}$ receptors by serotonin, while delayed emesis is thought to occur mainly through activation of NK1 receptors by substance $\mathrm{P}$. In other words, serotonin is the dominant mediator in the acute phase, while substance $\mathrm{P}$ becomes the dominant mediator in the delayed phase [28]. Therefore, our negative result may be due to our study evaluating patients only for the first $24 \mathrm{~h}$ postoperatively. Furthermore, palonosetron in this period may have sufficient effect on the NK1 receptor to prevent $\mathrm{PONV}$ through $5-\mathrm{HT}_{3} / \mathrm{NK} 1$ receptor cross-talk inhibition, resulting in masking of the effect of aprepitant on NK1 receptors.

One important result of our study is the finding that combination of aprepitant and palonosetron reduced the incidence of vomiting from $14 \%$ to $2 \%$ compared with palonosetron alone. This corresponds to an $86 \%$ relative reduction in the risk of vomiting during the first $24 \mathrm{~h}$ postoperatively. This is consistent with a previous finding by Lee et al. [18] of an $89 \%$ relative risk reduction for vomiting using aprepitant. Our results suggest that aprepitant does have an anti-vomiting effect, even though there was no statistical group difference due to the low incidence of vomiting even in the palonosetron alone group $(\mathrm{P}=0.111)$.

One limitation of this study was its relatively short evaluation period. We investigated our study medications for only the first 24 h postoperatively, but aprepitant and palonosetron have demonstrated efficacy in preventing both acute and delayed emesis [13]. Therefore, further studies on the delayed effects of aprepitant combined with palonosetron for prevention of PONV for up to $48 \mathrm{~h}$ postoperatively are needed.

In conclusion, a combination of aprepitant and palonosetron did not reduce the incidence of PONV to a greater extent than 
did palonosetron alone in the first $24 \mathrm{~h}$ after surgery in female patients receiving fentanyl IV-PCA.

\section{Acknowledgments}

This study was supported by the Soonchunhyang University Research Fund.

\section{ORCID}

Jae Hwa Yoo, https://orcid.org/0000-0003-0675-0761

Soon Im Kim, https://orcid.org/0000-0001-8884-4096

\section{References}

1. Gan TJ, Diemunsch P, Habib AS, Kovac A, Kranke P, Meyer TA, et al. Consensus guidelines for the management of postoperative nausea and vomiting. Anesth Analg 2014; 118: 85-113.

2. Watcha MF, White PF. Postoperative nausea and vomiting. Its etiology, treatment, and prevention. Anesthesiology 1992; 77: 162-84.

3. Diemunsch P, Joshi GP, Brichant JF. Neurokinin-1 receptor antagonists in the prevention of postoperative nausea and vomiting. Br J Anaesth 2009; 103: 7-13.

4. Ho KY, Gan TJ. Pharmacology, pharmacogenetics, and clinical efficacy of 5-hydroxytryptamine type 3 receptor antagonists for postoperative nausea and vomiting. Curr Opin Anaesthesiol 2006; 19: 606-11.

5. Rojas C, Thomas AG, Alt J, Stathis M, Zhang J, Rubenstein EB, et al. Palonosetron triggers 5-HT(3) receptor internalization and causes prolonged inhibition of receptor function. Eur J Pharmacol 2010; 626: 193-9.

6. Gralla R, Lichinitser M, Van Der Vegt S, Sleeboom H, Mezger J, Peschel C, et al. Palonosetron improves prevention of chemotherapyinduced nausea and vomiting following moderately emetogenic chemotherapy: results of a double-blind randomized phase III trial comparing single doses of palonosetron with ondansetron. Ann Oncol 2003; 14: 1570-7.

7. Eisenberg P, Figueroa-Vadillo J, Zamora R, Charu V, Hajdenberg J, Cartmell A, et al. Improved prevention of moderately emetogenic chemotherapy-induced nausea and vomiting with palonosetron, a pharmacologically novel 5-HT3 receptor antagonist: results of a phase III, single-dose trial versus dolasetron. Cancer 2003; 98: 2473-82.

8. Rojas C, Stathis M, Thomas AG, Massuda EB, Alt J, Zhang J, et al. Palonosetron exhibits unique molecular interactions with the 5-HT3 receptor. Anesth Analg 2008; 107: 469-78.

9. Chun HR, Jeon IS, Park SY, Lee SJ, Kang SH, Kim SI. Efficacy of palonosetron for the prevention of postoperative nausea and vomiting: a randomized, double-blinded, placebo-controlled trial. Br J Anaesth 2014; 112: 485-90.

10. Candiotti KA, Kovac AL, Melson TI, Clerici G, Joo Gan T. A randomized, double-blind study to evaluate the efficacy and safety of three different doses of palonosetron versus placebo for preventing postoperative nausea and vomiting. Anesth Analg 2008; 107: 445-51.

11. Kovac AL, Eberhart L, Kotarski J, Clerici G, Apfel C. A randomized, double-blind study to evaluate the efficacy and safety of three different doses of palonosetron versus placebo in preventing postoperative nausea and vomiting over a 72-hour period. Anesth Analg 2008; 107 : 43944.

12. Hesketh PJ, Grunberg SM, Gralla RJ, Warr DG, Roila F, de Wit R, et al. The oral neurokinin-1 antagonist aprepitant for the prevention of chemotherapy-induced nausea and vomiting: a multinational, randomized, double-blind, placebo-controlled trial in patients receiving high-dose cisplatin--the Aprepitant Protocol 052 Study Group. J Clin Oncol 2003; 21: 4112-9.

13. Rojas C, Raje M, Tsukamoto T, Slusher BS. Molecular mechanisms of 5-HT(3) and NK(1) receptor antagonists in prevention of emesis. Eur J Pharmacol 2014; 722: 26-37.

14. Hesketh PJ, Bohlke K, Lyman GH, Basch E, Chesney M, Clark-Snow RA, et al. Antiemetics: American society of clinical oncology focused guideline update. J Clin Oncol 2016; 34: 381-6.

15. Diemunsch P, Gan TJ, Philip BK, Girao MJ, Eberhart L, Irwin MG, et al. Single-dose aprepitant vs ondansetron for the prevention of postoperative nausea and vomiting: a randomized, double-blind phase III trial in patients undergoing open abdominal surgery. Br J Anaesth 2007; 99: 202-11.

16. Gan TJ, Apfel CC, Kovac A, Philip BK, Singla N, Minkowitz H, et al. A randomized, double-blind comparison of the NK1 antagonist, aprepitant, versus ondansetron for the prevention of postoperative nausea and vomiting. Anesth Analg 2007; 104: 1082-9.

17. Diemunsch P, Apfel C, Gan TJ, Candiotti K, Philip BK, Chelly J, et al. Preventing postoperative nausea and vomiting: post hoc analysis of pooled data from two randomized active-controlled trials of aprepitant. Curr Med Res Opin 2007; 23: 2559-65.

18. Lee SJ, Lee SM, Kim SI, Ok SY, Kim SH, Park SY, et al. The effect of aprepitant for the prevention of postoperative nausea and vomiting in patients undergoing gynecologic surgery with intravenous patient controlled analgesia using fentanyl: aprepitant plus ramosetron vs ramosetron alone. Korean J Anesthesiol 2012; 63: 221-6.

19. Apfel CC, Läärä E, Koivuranta M, Greim CA, Roewer N. A simplified risk score for predicting postoperative nausea and vomiting: conclusions from cross-validations between two centers. Anesthesiology 1999; 91: 693-700. 
20. Apfel CC, Korttila K, Abdalla M, Kerger H, Turan A, Vedder I, et al. A factorial trial of six interventions for the prevention of postoperative nausea and vomiting. N Engl J Med 2004; 350: 2441-51.

21. Habib AS, El-Moalem HE, Gan TJ. The efficacy of the 5-HT3 receptor antagonists combined with droperidol for PONV prophylaxis is similar to their combination with dexamethasone. A meta-analysis of randomized controlled trials. Can J Anaesth 2004; 51: 311-9.

22. Vallejo MC, Phelps AL, Ibinson JW, Barnes LR, Milord PJ, Romeo RC, et al. Aprepitant plus ondansetron compared with ondansetron alone in reducing postoperative nausea and vomiting in ambulatory patients undergoing plastic surgery. Plast Reconstr Surg 2012; 129 : 519-26.

23. Trimas SJ, Trimas MD. Use of aprepitant and factors associated with incidence of postoperative nausea and vomiting in patients undergoing facial plastic surgery. JAMA Facial Plast Surg 2015; 17: 251-5.

24. Stathis M, Pietra C, Rojas C, Slusher BS. Inhibition of substance P-mediated responses in NG108-15 cells by netupitant and palonosetron exhibit synergistic effects. Eur J Pharmacol 2012; 689: 25-30.

25. Thomas AG, Stathis M, Rojas C, Slusher BS. Netupitant and palonosetron trigger NK1 receptor internalization in NG108-15 cells. Exp Brain Res 2014; 232: 2637-44.

26. Aapro M, Rugo H, Rossi G, Rizzi G, Borroni ME, Bondarenko I, et al. A randomized phase III study evaluating the efficacy and safety of NEPA, a fixed-dose combination of netupitant and palonosetron, for prevention of chemotherapy-induced nausea and vomiting following moderately emetogenic chemotherapy. Ann Oncol 2014; 25: 1328-33.

27. Hesketh PJ, Rossi G, Rizzi G, Palmas M, Alyasova A, Bondarenko I, et al. Efficacy and safety of NEPA, an oral combination of netupitant and palonosetron, for prevention of chemotherapy-induced nausea and vomiting following highly emetogenic chemotherapy: a randomized dose-ranging pivotal study. Ann Oncol 2014; 25: 1340-6.

28. Hesketh PJ, Van Belle S, Aapro M, Tattersall FD, Naylor RJ, Hargreaves R, et al. Differential involvement of neurotransmitters through the time course of cisplatin-induced emesis as revealed by therapy with specific receptor antagonists. Eur J Cancer 2003; 39: 1074-80. 